\title{
DIFFERENCES IN THE SPATIAL DISTRIBUTION AND CHARACTERISTICS OF URBAN BEGGARS: THE CASE OF THE SANGLAH DISTRICT IN DENPASAR (INDONESIA)
}

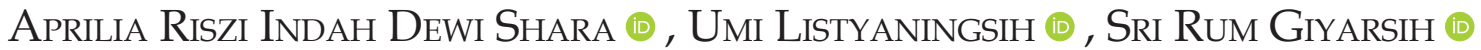

\begin{abstract}
Faculty of Geography, Universitas Gadjah Mada, Jalan Kaliurang, Sekip Utara, Bulaksumur Sinduadi Sleman, Senolowo, Sinduadi, Kec, Mlati, Kabupaten Sleman, Daerah Istimewa Yogyakarta 5528
\end{abstract}

Manuscript received: September 12, 2020

Revised version: November 9, 2020

\begin{abstract}
Shara A.R.I.D., Umi L., GIYARsih S.R., 2020. Differences in the spatial distribution and characteristics of urban beggars: The case of the Sanglah district in Denpasar (Indonesia). Quaestiones Geographicae 34(9), Bogucki Wydawnictwo Naukowe, Poznań, pp. 109-119. 3 tables, 4 figs.

AвSTRACт: The study set out to analyse the differences in the characteristics and spatial distribution of urban beggars in Sanglah, Denpasar City. It employed survey research for data collection by observation, structured interviews with a questionnaire, and documentation. These data were later processed and analysed in a quantitative descriptive manner. The results show that, based on religion, there were two groups of beggars, namely Muslim and Hindu. Spatially, the Hindu beggars disregarded the religion of the people they implored, whereas the Muslim beggars would only target the houses and shops owned by Muslims. Those two class of beggars differ in languages, bagging duration, daily-earning, clothing, and sympathy-drawing strategy during the panhandling.
\end{abstract}

KEYWORDS: characteristics of beggars, spatial distribution, urban beggars, urban poverty, Indonesia

Corresponding author: Sri Rum Giyarsih, Universitas Gadjah Mada Jl. Kaliurang, Sekip Utara, Bulaksumur Sinduadi Sleman, Senolowo, Sinduadi, Kec. Mlati, Kabupaten Sleman, Daerah Istimewa Yogyakarta 55281, e-mail: srirum@ugm.ac.id

\section{Introduction}

Begging or panhandling is not a new issue in urban development, but this does not mean that the existence of beggars is negligible. The situation implies that the policies implemented to deal with beggars contribute to whether or not they appear and their number grows in a region. According to Thamrin and Ritonga (2018), the issue of urban beggars has never been entirely solved by either the government or civil society. Broun (2010) states that begging or panhandling is one of the antisocial patterns of behaviour found in almost every country, especially in developing one. Nigeria is one of many developing countries with a similar beggar-related issue to Indonesia. Bukoye (2015) confirms that the mushrooming of beggars has long been a social issue in Nigeria and has turned into the major drawback of global development. The same case is detected in Ghana and, according to Fuseini and Daniel (2018), the poverty of parents affects the number of child beggars in the country.

Begging is a phenomenon that widely differs from one context to another. It is commonly practiced to survive (Muñoz 2018). Beggars in 
urban areas in Indonesia can generally be found in large cities like Denpasar. The scene that the city offers is filled with beggars panhandling for money in heavily congested areas like supermarkets, markets, shops, mosques, and traffic light corners (Shara 2019). Kamruzzaman and Hakim (2015) concur that beggars may be found in public places, such as along transport routes, city parks and markets. Graham and Grisard (2019) give an example that to show generosity or wealth, people drop or give coins to beggars they meet, and this action encourages the existence of beggars today.

Mansour (2017) states that several factors are known to influence a person to resort to or prefer begging. These are poverty, homelessness, low education, illiteracy, unemployment, family problems, psychological causes, and economic difficulties. Khan (2018) also explains that begging is the last choice a person makes to deal with poverty. In response to these underlying causes, beggars exist in large cities with rapid development, including Denpasar City, Indonesia. Several previous researches show that education is the main factor influencing poverty in Bali (Endrayani, Dewi 2016; Paramita, Suresmiathi 2012; Putri, Yuliarmi 2011; Saputra, Dewi 2010). They are usually found on streets nearby traffic lights or in centres of activity, places of worship, settlements, and other categorically strategic locations. Similarly, Bernstein (2019) reveals that beggars are commonly found in dense urban centres where they can take advantage of the structural inequality of wealth and mobility between them and tourists.
In general, beggars in Denpasar City come from the rural areas which are not geographically advantageous. Those beggars come from Muntigunung (a sub-village of Tianyar Barat) and Pedahan (a sub-village in Tianyar Tengah, Karangasem Regency, Bali Province) (Iqbali 2005). They lack resources to make a living, whether it is tangible resources such as arable land or intangible resources such as public services. Those conditions force the villager to migrate to the nearby city to make a living (Hartomo and Aziz 1997). The beggars of Muntigunung, called pengemis munti, are not only found in the city but also other regencies in a small number. However, the distribution of beggars in the city continuously changes with the entry of beggars from outside Bali.

Based on the data of the Social Service of Denpasar City, East Java Province has been the largest contributor to the number of beggars in the city since 2012. In this year, many beggars were arrested on-site during the raids, and as seen in Table 1, this assertion is confirmed by the data of the Social Service in 2018.

Table 1 shows that a large number of beggars in Denpasar City, as characterised by their religion, are Muslims and Hindus. The two dominant religions among the beggars in the city, particularly in the Sanglah District, may create a uniquely interesting phenomenon to study because they can lead to differences in the characteristics and spatial distribution of beggars in this region. From the perspective of beggars, Sanglah is the most 'promising' district in the city. Per Local Regulation No. 27 of 2011 on the Spatial

Table 1. General overview of beggars in Denpasar City, 2018.

\begin{tabular}{|l|c|c|}
\hline \multicolumn{1}{|c|}{ Variables } & \multicolumn{1}{|c|}{ Descriptions } \\
\hline Religion & \multicolumn{2}{|c|}{ Islam: 49, Hinduism: 22, Christianity: 2, Catholicism: 1} \\
\hline Sex & $0-4: 2$ & Male: 37, Female: 35 \\
\hline Age & $5-9: 1$ & $40-39: 3$ \\
& $10-14: 5$ & $45-49: 1$ \\
& $15-19: 1$ & $50-54: 10$ \\
& $20-24: 2$ & $55-59: 8$ \\
& $25-29: 1$ & $60-64: 9$ \\
Locations where beggars can be & $30-34: 7$ & $65+: 13$ \\
found & Mahendradatta, Seroja, Gatsu, Sesetan, Ubung, Peguyangan, Gunung Ta- \\
& lang, Pulau Kawe, Penatih, Pulau Moyo, Pulau Batanta, Teuku Umar, Imam \\
& Bonjol, Diponegoro, Gajah Mada, Sulawesi, Subur, A.Yani, Waturenggong, \\
& Masjid Agung Sudirman, Gunung Agung, Hayam Wuruk, Malboro, Sopu- \\
& tan, Pemogan \\
\hline
\end{tabular}

Source: Social Service of Denpasar City, 2018. 
Planning of Denpasar City in 2011-2031 Article 15 (service centre system in the city), Sanglah is the designated centre for economic activity, higher education, and regional healthcare service. In other terms, it is the downtown of Denpasar.

This study aims to analyse the difference in characteristics and spatial distribution among beggars in Sanglah comprehensively from the perspective of urban geography. In the longer term, this research is expected to provide many benefits, such as an input to the political decision-making process in addressing the issue of beggars in Denpasar City in general and Sanglah in particular.

\section{Research method}

The study was designed with survey research. According to Goodall (1987) in Yunus (2010), survey research is an investigation or research aimed at collecting the facts of existing symptoms and looking for factual information from a group or an area by census or sampling. Finterbusch (1983) in Yunus (2010) also explains that "a survey is an investigation that uses questionnaires to collect data". Based on these definitions, the research used a census and a questionnaire as tools to collect or record data on two variables, namely the characteristics and spatial distributions of beggars in Sanglah. The characteristics were obtained through structured interviews, while the spatial distributions were determined by field observation using GPS. Beggars in Sanglah were the object or target of this quantitative research.

This study was conducted in the Sanglah District for two months. What was used was accidental sampling to select interviewees. The population of this study is the whole beggar population found in Sanglah from 07:00 a.m. to 4:00 p.m. $(\mathrm{UTC}+8)$ on the weekend (Friday-Sunday). This population was chosen because the author assumes a weekend is the peak of beggar appearance on streets as Friday is the worship day for Muslims and Saturday and Sunday are public holidays. The data used in this study are listed in Table 2.

The data will be processed and analysed further with cross-tab analysis to describe the difference between beggar characteristics (Muslim beggars and Hindu beggars) and daily earned money.

The choice of the Sanglah District as a study area was based on several reasons:

1. Following the Local Regulation of Denpasar City, No. 27 of 2011 (Article 15(2)), Sanglah is a centre of economic activity, tertiary education, and regional-scale healthcare service.

2. Sanglah is a strategic area of high importance in social and public services (Article 61(5) of Regulation No. 27 of 2011).

3. The data acquired from the Social Service of Denpasar City show that beggars in the city are concentrated in Sanglah. The location of the study area is presented in Figure 1.

\section{Results and discussion}

The beggars in Sanglah, Denpasar, have different characteristics, including religion. Most of them are Muslims and Hindus. Based on the results of the interviews with 41 respondents, 28 of them were Muslims (68.3\%), while the remaining $13(31.7 \%)$ were Hindus. In other terms, the Muslim beggars had a larger proportion than the Hindu beggars. Because of their religious differences, they tend to show variations in their characteristics, spatial distribution, and even strategies in panhandling practices.

Based on their religion, beggarsinSanglah have different areas of origin. Muslim beggars come from several regions in East Java Province, namely Surabaya, Situbondo, Bondowoso, Jember, Blitar, Probolinggo, and Banyuwangi. Meanwhile, all Hindu beggars are from Muntigunung and

Table 2. Data acquisition method.

\begin{tabular}{|l|c|c|c|c|}
\hline \multicolumn{1}{|c|}{ Variable } & Data Type & Acquisition technique & Tools & Sources \\
\hline Characteristics of beggars & Primary & Interview & Questionnaires & Informant \\
\hline $\begin{array}{l}\text { Spatial distribution of beggars } \\
\text { Panhandling route } \\
\text { Place visited }\end{array}$ & Primary & Coordinate plotting & GPS & Field survey \\
\hline
\end{tabular}

Source: own study. 


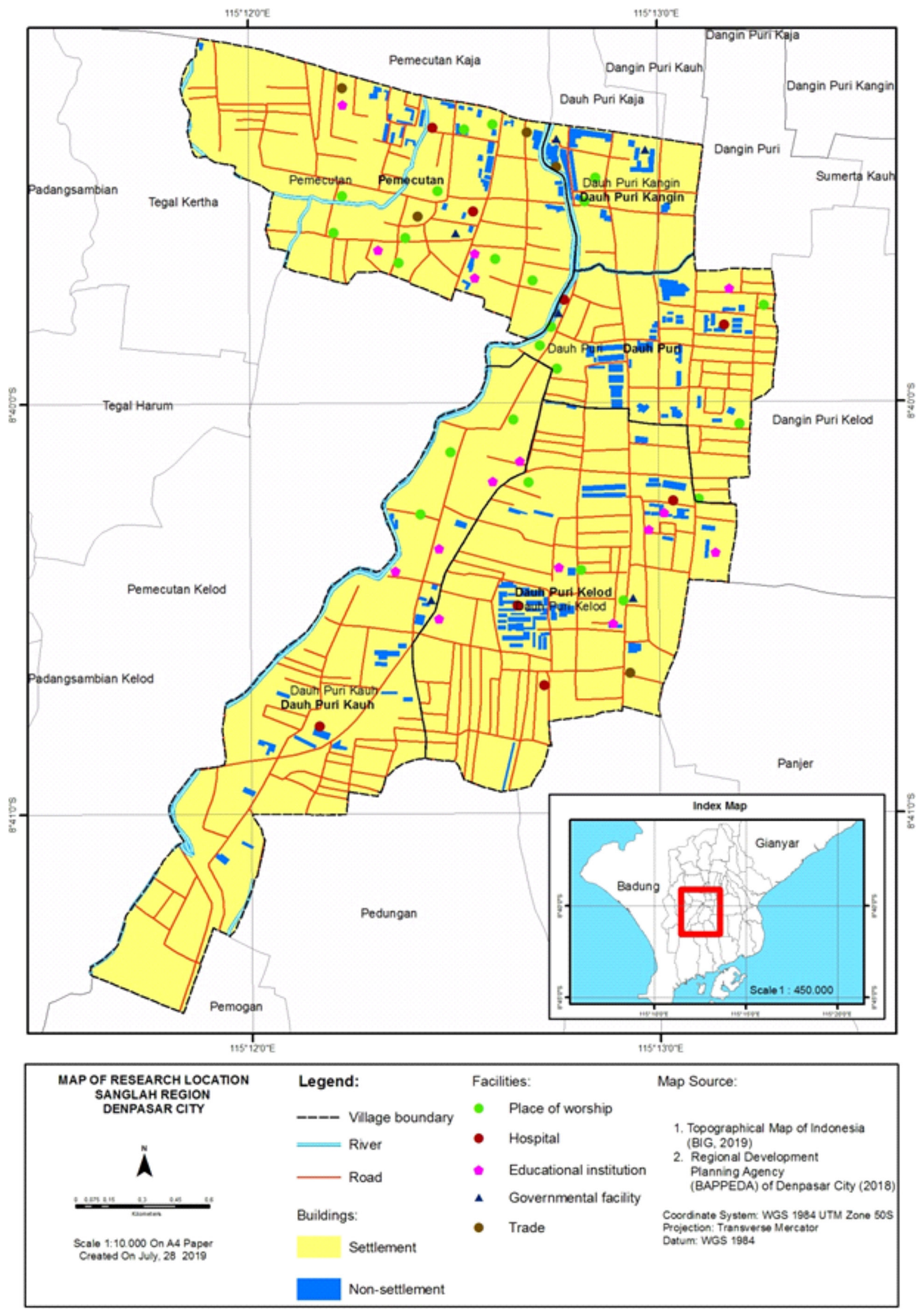

Fig. 1. The research location.

Source: own study. 


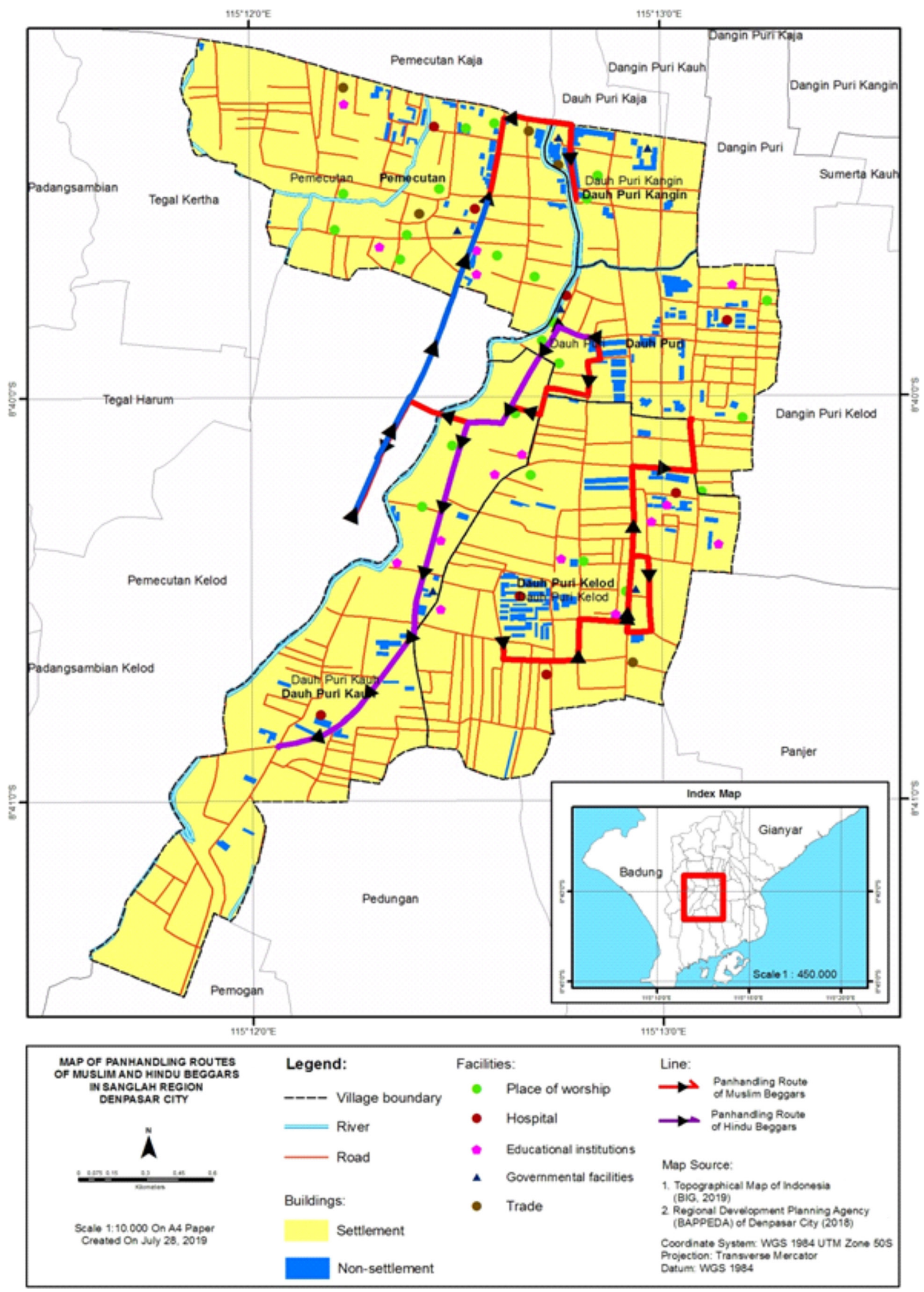

Fig. 2. The map of the panhandling routes of Muslim beggars in Sanglah. Source: primary data analysis, 2019. 
Pedahan Hamlets, Karangasem Regency. Aside from the area of origin, beggars from these two groups of religions have different spatial distribution. Spatially, beggars choose centres of activities or crowds to panhandle for money. Khan et al. (2016) suggest that the number of beggars in an area can vary by region. Generally, the targeted locations are determined by population density, the frequency of wealthy communities, big markets, and other crowded places. The sections below describe the variations in the spatial distribution of the panhandling locations of Muslim and Hindu beggars.

\section{The spatial distribution of Muslim and Hindu beggars in Sanglah}

During the field observation, two routes used by Muslim beggars to start their panhandling practices, i.e., from 07:00 a.m. WITA (Central Indonesian Time; UTC+08.00), were identified. Figure 2 shows the travel routes of beggars in the study area.

Two panhandling routes of Muslim beggars can be identified. The first one goes through the roads: Jalan Nusa Kambangan - Jalan Pulau Banda - Jalan Pulau Maluku - Jalan Pulau Biak - Jalan Imam Bonjol - Jalan Gajah Mada - Jalan Sulawesi - Jalan Hasanudin - Jalan Kalimantan. The second route is Jalan Pulau Kawe - Jalan Pulau Timor - Jalan Pulau Bali - Jalan Pulau Nias - Jalan Serma Made Pil - Jalan Waturenggong Jalan Diponegoro - Jalan PB. Sudirman. Although these routes do not overlap, they have similar characteristics. For instance, the first route includes Jalan Gadjah Mada, which is a heritage area functioning as a trade zone with typical old shopping buildings in Denpasar City, while the second route passes through the Diponegoro shopping area (Jalan Diponegoro).

The difference between the two routes lies in the visited healthcare facility, i.e., the second route has one, whereas the first route does not. The rest of the public places, such as settlements, shops, trade centres, and places of worship, are found in each route. Thomassen (2015) states that beggars in Rome are seen in many churches, supermarkets, minimarkets, schools, ATMs, and magazine shops. Similarly, Mirjat et al. (2017) mention restaurants, supermarkets, recreational parks, places of worship, educational institutions, stations, and banks as the most frequently visited places for panhandling. Accordingly, the practice of begging takes place in crowded areas.

Based on Figure 2, Muslim beggars (red lines) appear to form two patterns on their begging routes, while Hindu beggars (light red lines) form only one pattern. The targeted areas of Hindu beggars are more scattered than their Muslim counterparts, which form a clustered pattern. However, their routes of panhandling were observed as a pattern because Hindu beggars in Sanglah were larger in number and more easily found along these routes than Muslim beggars.

In general, Muslim beggars start their activities at 07:00 a.m.-2:00 p.m. WITA. They visit settlements and shops whose owners must be Muslims. In other words, they do not visit non-Muslim traders or shop- and homeowners due to self-restriction based on their belief. This rule applies to all Muslim beggars on the first and second routes. Furthermore, Muslim beggars on route one ride on a pickup truck for IDR 2,000/ person to move from the trade centre to the shopping area on Jalan Gajah Mada. The distance between the two sites is about $1.5 \mathrm{~km}$, and riding

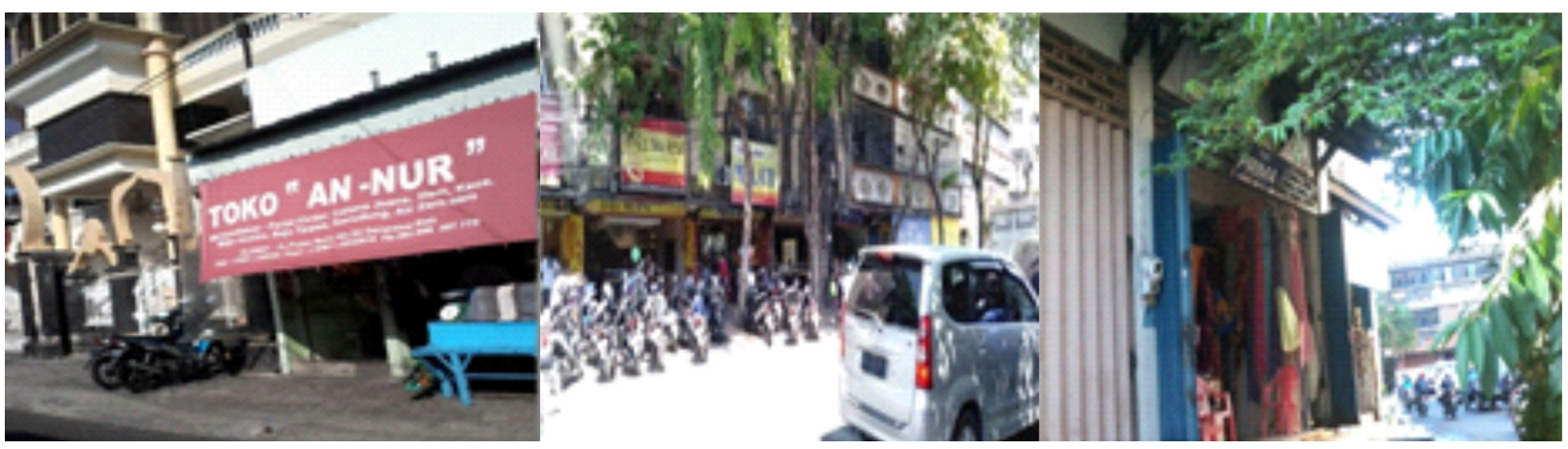

Fig. 3. Areas targeted by Muslim beggars in Sanglah. Source: personal documentation, 2019. 
on a pickup truck can save time and energy. The targeted sites in the shopping area are gold and clothes shops. Furthermore, beggars on routes one and two finish their daily panhandling at some of the closest places of worship at the end of their route.

The field observation identified three mosques used by beggars at the end of their daily panhandling activity. They were Masjid Raya Ukhuwah on route one and Masjid An-Nur dan Masjid Raya Sudirman on route two. Beggars would wait for the pilgrims to finish their midday prayer at these mosques before returning home. Some of them were picked up by their families, while the others used public transport for USD 35 cents/person. Figure 3 shows some of the areas targeted by Muslim beggars for panhandling for money in Sanglah.

On the basis of the discussion above, the spatial distribution of beggars depends on the characteristics of the targeted areas. These areas have to be strategic locations where economic and human activities take place and are situated close to one another. In connection to this, the spatial distribution forms a clustered pattern, i.e., where several objects form a group and are located close to each other. The proximity of one object to another increases the panhandling efficiency in terms of time and energy. In line with this, Sirojuzilam (2006) explains that the location theory is a theoretical explanation that is associated with the spatial plan of economic activity. It has always been linked to the geographical location of limited resources, which in turn will affect and impact the location of various economic and social activities. This theory is perceived as a representation of the phenomena occurring in Denpasar City, especially in Sanglah.
Based on the results of the two-month survey, Hindu beggars did not limit the targeted areas for their panhandling. This finding is contrary to Muslim beggars who choose areas or objects owned by Muslims. In conclusion, Hindu beggars are more flexible than Muslim beggars in the places they visit. Hindu beggars do not pay attention as to whether the owners of these objects are Hindus, Muslims, Christians, or others. For instance, Hindu beggars were seen asking for money in Muslim food stalls, as well as mobile phone stores, residential sites, and shops owned by non-Hindus. Their unlimited selection of targeted areas is attributable to their status as Balinese natives that come with an advantage of familiarity and feeling of being free to visit any places they want.

Spatially, Hindu beggars do not form a definite pattern in their practice. Unlike Muslim beggars, they target areas flexibly and, therefore, their practice of begging does not form a clustered pattern. Hindu beggars also differ from their Muslim counterparts in the duration of panhandling. Muslim beggars start in the morning and end at noon, where they sit in silence on the terrace of the mosque while waiting for the pilgrims to finish their worship. Meanwhile, Hindu beggars were seen in several areas in Sanglah from 8:00 a.m. until 4:00 p.m. WITA. Some of them were still found in front of convenience stores, such as Indomaret or Alfamart on Jalan Nusa Kambangan, at 7:00 p.m. WITA.

Figure 4 shows the locations visited by Hindu beggars in Sanglah. The irregular pattern is concluded as the effect of no time regulation that binds them, unlike Muslim beggars. For this reason, the spatial distribution of Muslim and Hindu beggars differ in their targeted or visited objects,

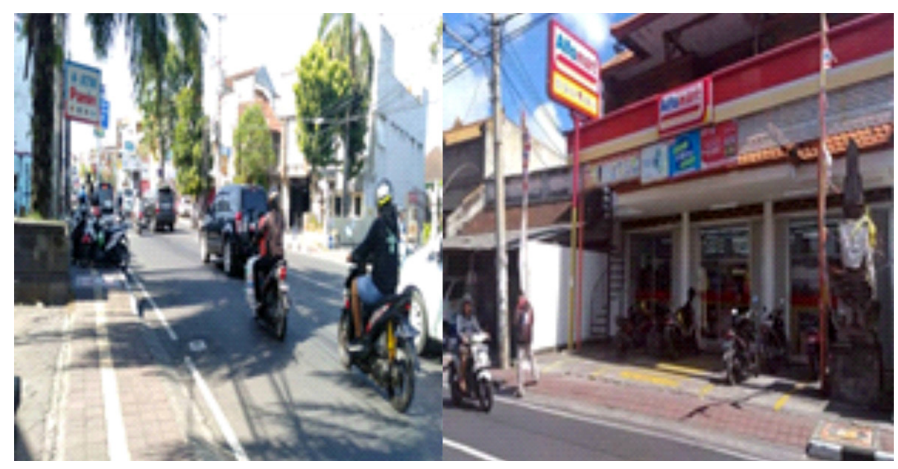

Fig. 4. Areas targeted by Hindu beggars in Sanglah. Source: personal documentation, 2019. 
routes, and the duration of panhandling in one day. These variations are apparent when depicted in a map and correlated with the route of panhandling between the two groups of beggars.

\section{Beggar characteristics in the Sanglah District}

Hindu beggars carry out their panhandling activities from morning until afternoon (08:00 a.m.-4:00 p.m. WITA) or from afternoon until evening (later than 10:00 a.m.-7:00 p.m. WITA). The most significant difference between Muslim and Hindu beggars is that the latter does not visit the places of worship for Muslims. Also, they do not ask for money at Pura or Balinese Hindu temple on a routine basis because this facility is used during certain ceremonies only.

The interviews with Hindu beggars revealed that they did not spend much time around Sanglah. Instead, they walked along Jalan Teuku Umar, which is a shopping area, through Jalan Batanta Island to reach Pemogan, South Denpasar. At the time of field observation, Hindu beggars were seen around Pemogan at 3:00 p.m. WITA. Afterward, they walked to Simpang Siur (Dewa Ruci Intersection) in Kuta, Badung, until evening. Simpang Siur is indeed very crowded because it is the main route to a world-renowned tourist destination (Kuta Beach), some souvenir shops, and the airport. On the contrary, Hindu beggars did not spend much time in Sanglah because of increasingly frequent raids by the government and the mushrooming of Muslim beggars in the area. Aside from reduced income, panhandling for money in Sanglah means a higher risk of being arrested because the Public Order Enforcers have categorised Sanglah as the centre of mendicancy in Denpasar City. Therefore, Hindu beggars prefer to look for crowds in other regions.

Muslim and Hindu beggars also have different panhandling strategies. These strategies are clothing style, language, strategy to draw sympathy, duration of panhandling, and daily earned money. These differences are explained below.

\section{Clothing style}

Beggars wear two styles of clothing, namely normal daily and tattered clothing. Muslim beggars wear normal clothing, i.e., long clothes, skirts, and headscarves for Muslim women and long- and short-sleeve shirts modified from Chinese tui-khim clothes for Muslim men. Meanwhile, Hindu beggars wear tattered clothes. The field observation proved that Muslim beggars were indeed distinct from Hindu beggars, and the most noticeable difference was their clothing style.

Because Muslim beggars wear regular daily clothing, they are not easily recognised. Without prior knowledge, people will not immediately perceive them as beggars. Unlike them, Hindu beggars tend to wear dirty and tattered clothes that make them quickly recognised. Despite the distinctive clothing styles, there is a similarity between the two groups of beggars, namely a bag hanging on the left shoulder. The researchers found that almost all beggars, especially female, carried a reusable shopping bag.

\section{Language}

In the practice of panhandling, Muslim beggars speak Indonesian, while Hindu beggars use Balinese. Religion affects how beggars communicate with potential benefactors. In this case, Hindu beggars tend to use Balinese because it is the local language used daily in their interaction with the community. As for Muslim beggars, they use Indonesian as a communication tool because they do not speak Balinese regularly.

\section{Strategy to draw sympathy}

In reality, panhandling is a two-way interaction in which a person asks for money using various strategies to potential benefactors who decide to ignore or grant him/her money (Qiao et al. 2017). Therefore, a strategy to draw the sympathy of potential benefactors is essential in this practice. In the study area, Hindu beggars uniformly apply one strategy, that is, putting on pitiful facial expression. Meanwhile, Muslim beggars adopt various strategies, including praying for prospective benefactors, putting on their pleading facial expressions, and playing musical instruments to attract attention.

These findings are in line with Erlandsson et al. (2019). Their study has found that beggars in Sweden sell magazines, play musical instruments, or ask for money from passersby while sitting with a mug near grocery stores. Kongoley (2017) adds that street beggars in Freetown, Sierra Leone, pretend to be sick and disguise themselves 
as blind, deaf, or paralysed persons to draw sympathy. Also, in Heraklion, Greece, the strategy of panhandling includes sitting in shabby or tattered clothing, approaching the tourists one by one, playing music and singing world-famous songs, and performing some attractions, such as dressing up like Charlie Chaplin (Andriotis 2016). These entire strategies are intended to draw the sympathy of prospective benefactors or to make them feel sorry and, then, give money to beggars.

\section{Duration of panhandling}

Generally, Muslim beggars work less than eight hours a day, from morning until the midday prayer. Meanwhile, Hindu beggars usually work longer. However, this research found that out of the 41 respondents, only six of them (14.6\%) worked more than eight hours, while the remaining 35 beggars $(85.4 \%)$ worked less than eight hours. The dominance of working for less than eight hours corresponds to the practice of begging identified in Kumasi, Ghana. Sekyere et al. (2018) divide the beggars in Kumasi, Ghana, into two groups, namely those panhandling between 5:00 and 10:00 in the morning and between 3:00 p.m. and 7:00 p.m.. In other words, the duration of begging in Kumasi is merely $4-5$ hours. Likewise, the beggars in Sanglah usually work for 6-7 hours. This duration has its advantage, i.e., the practice of begging can be conducted flexibly, freely, and quickly.

\section{Daily earned money}

The results of the cross-tabulation analysis between the religion of the beggars and their daily earned money are presented in Table 3.

Based on the results of the cross-tabulation analysis in Table 3, the average money earned by Hindu beggars per day is higher than that of their

Table 3. Relationship between daily earned money and the religion of beggars.

\begin{tabular}{|c|c|c|c|c|c|c|}
\hline \multirow{3}{*}{ Daily earned money } & \multicolumn{4}{|c|}{ Religion } & \multirow{2}{*}{\multicolumn{2}{|c|}{ Total }} \\
\hline & \multicolumn{2}{|c|}{ Islam } & \multicolumn{2}{|c|}{ Hinduism } & & \\
\hline & $\mathrm{N}$ & $\%$ & $\mathrm{~N}$ & $\%$ & $\mathrm{~N}$ & $\%$ \\
\hline$<$ IDR 50,000 & 3 & 7.3 & 0 & 0 & 3 & 7.3 \\
\hline IDR 50,000-100,000 & 13 & 31.7 & 3 & 7.3 & 16 & 39.0 \\
\hline > IDR 100,000 & 12 & 29.3 & 10 & 24.4 & 22 & 53.7 \\
\hline Total & 28 & 68.3 & 13 & 31.6 & 41 & 100 \\
\hline
\end{tabular}

Source: primary data analysis, 2019.
Muslim counterparts. Unlike Muslim beggars, no Hindu beggar makes less than USD 3.52 (IDR 50,000.00) per day. Also, 10 out of the 13 Hindu beggars in Sanglah earn more than USD 7.03 (IDR 100,000.00), while the other three beggars make USD 3.52-7.03 per day. Meanwhile, 12 out of the 28 Muslim beggars earn more than USD 7.03, 12 of them earn USD 3.52-7.03, and the other three beggars make less then USD 3.52 per day.

A previous study in Riau, Indonesia, shows a similar result which states that a beggar's earning from panhandling ranged approximately IDR 50,000 to 200,000 (Lestari 2014). While in Surakarta, Central Java, Indonesia, panhandling only earn less than IDR 50,000 (Setyaningrum 2014). These studies show different economic conditions among places in Indonesia. However, those earning means nothing if not linked to the cost of living to know if someone falls below the poverty line.

According to Statistics Indonesia (BPS), the term of poverty describes a condition where a person's income falls below the poverty line, which is the minimum amount of funds to fulfil daily needs such as food, shelter, health and clothing. According to the Cost of Living Survey (Survey Biaya Hidup) by Statistics Indonesia, the minimum cost of living in Denpasar is as much as USD 375.37 (IDR 5,336,109.00). Hence, the monthly income of the beggar, which is mostly no more than USD 21.10 (IDR 3,000,000.00), is arguably not enough to fulfil their needs for decent living. Beggars cope to survive by suppressing the expenses, such as living in a slum.

This condition also occurs in India. According to Frederick et al. (2016), the average money earned by beggars in India is Rs. 200 or IDR 40,000 a day. This figure is considered high, therefore beggars refuse to leave panhandling as their main economic activity. This way, beggars can make easy money without much effort. Malarvizhi and Geetha (2016) explain that panhandling has become a profession that is difficult to leave because it does not require a large amount of energy to earn much money.

\section{Conclusion}

This study has identified the variations in the characteristics and spatial distribution of beggars 
in Sanglah, Denpasar City. In general, beggars in this region are divided into Muslim and Hindu. Muslim beggars come from Situbondo, Bondowoso, Jember, Blitar, Probolinggo, and Banyuwangi (East Java Province), while Hindu beggars are from Muntigunung and Pedahan Villages in Karangasem Regency (Bali Province). Their routes of panhandling differ in the visited places of worship. Unlike Muslim beggars, Hindu beggars do not visit any mosques. Also, they do not pay attention to the religion of owners of their targeted areas or buildings. On the contrary, Muslim beggars visit houses and shops owned by Muslims only. Hindu beggars wear tattered clothing, while their Muslim counterparts wear normal daily clothes (Muslim clothes). When interacting with potential benefactors, the former group speaks Balinese, while the latter uses Indonesian. Muslim beggars try to draw sympathy by praying for prospective benefactors, putting on a pleading or pitiful facial expression, and playing musical instruments to attract attention, while Hindu beggars only have one strategy, that is, putting on pleading facial expressions. Based on the duration of panhandling, Muslim beggars start at 7:00 a.m. until 1:00 p.m. WITA, while Hindu beggars work between 8:00 a.m. and 4:00 p.m. WITA and between 10:00 a.m. and 7:00 p.m. WITA. Hindu beggars make USD 3.52-7.03 per day, while Muslim beggars earn from less than USD 3.52 to more than 7.03 a day.

Based on these findings, the study recommends further in-depth research to examine other variables related to the reasons for panhandling. A further qualitative research will help to understand these issues better because this study has only been able to describe the difference between the general characteristics of the two groups of beggars.

\section{Acknowledgment}

The authors would like to thank Dr. Lutfi Muta'ali and Dr. Agus Joko Pitoyo for their invaluable input.

\section{References}

Andriotis K., 2016. Beggars-tourists' interactions: An unobtrusive typological approach. Tourism Management 52: 64-73. doi: 10.1016/j.tourman.2015.06.006.
Bernstein J.D., 2019. Begging to travel: Begpacking in Southeast Asia. Annals of Tourism Research 77: 161-163.

Broun, Idiege B., Ube M., Bisong MD, 2010. Counseling youth against drug abuse: Implication for human development. Conference proceeding. 34th Annual SCASSON conference.

Bukoye R.O., 2015. Case study: Prevalence and consequences of streets begging among adults and children in Nigeria, Suleja metropolis. Procedia - Social and Behavioral Sciences 171: 323-333.

Endrayani N.K.E., Dewi M.H.U., 2016. Analisis Faktor-Faktor Yang Mempengaruhi Tingkat Kemiskinan Kabupaten/Kota Di Provinsi Bali (Analysis of factors influencing poverty in regency/cities in Bali Province, Indonesia). E-Jurnal Ekonomi Dan Bisnis Universitas Undayana 5(1): 63-88.

Erlandsson A., Nilsson A., Tinghög G., Andersson D., Västfjäll D., 2019. Donations to outgroup charities, but not ingroup charities, Predict helping intentions toward street-beggars in Sweden. Nonprofit and Voluntary Sector Quarterly 48(4): 814-838.

Frederick A., Joseph D., Srivastava H., 2016. Begging in India: Barricading the sustainable financial development. IRA-International Journal of Management $\mathcal{E}$ Social Sciences (ISSN 2455-2267) 3(3). doi:http://dx.doi.org/10.21013/ jmss.v3.n3.p4.

Fuseini T., Daniel M., 2018. Exploring the stressors and resources of Muslim child beggars in Dagbon of Northern Ghana in the context of child rights and existing realities. Cogent Social Sciences 4. https:/ / doi.org/10.1080/233118 86.2018.1542955.

Graham C., Grisard C., 2019. Rich man, poor man, beggar man, thief: Accounting and the stigma of poverty. Critical Perspectives on Accounting 59: 32-51.

Hartomo and Aziz, 1997. Ilmu Sosial Dasar (Social Science). Bumi Aksara, Jakarta.

Iqbali S., 2005. Studi Kasus Gelandangan-Pengemis (Gepeng) Di Kecamatan Kubu Kabupaten Karangasem (Study on the case of urban beggars in the Kubu District, Karangasem Regency, Bali). Jurnal Kependudukan dan Pengembangan Sumber Daya Manusia 4(1). Universitas Udayana, Jimbaran.

Kamruzzaman Md., Hakim Md.A., 2015. Socio-economic status of child beggars in Dhaka City. Journal of Social Sciences and Humanities 1(5). Mawlana Bhashani Science and Technology University, Bangladesh.

Khan I., 2018. Socio-economic disparities among beggars in different locations of district Lahore_Pakistan. International Journal of European Studies 2(1): 1-7. doi: 10.11648/j. ijes.20180201.11.

Khan M.M., Hossain M.K., Hasina N., Uddin S., Ferdousi M., 2016. Status and social evaluation towards beggars in Bangladesh: Context of Sylhet City. International Journal of Social Science Studies 4(6). E-ISSN 2324-8041.

Kongoley P.S., 2017. The impact of street begging on the freetown municipality. International Journal of Scientific and Research Publication 7(7): 2250-3153.

Lestari P., 2014. Studi Tentang Kategorisasi Pengemis Dikota Pekanbaru (Categorisation of urban beggars (Case: Pekanbaru, Riau)). Jurnal Online Mahasiswa, FISIP Universitas Riau 2(1): 1-13.

Malarvizhi V., Geetha K.T., 2016. Socio-economic issues of beggary: A study of beggars in Coimbatore City. IRA-International Journal of Management and Social Sciences 3(2): 2455-2267. https:/ / dx.doi.org/10.21013/jmss.v3.n2.p8. 
Mansour E., 2017. An explanatory study into the information seeking-behaviour of Egyptian beggars. Journal of Librarianship and Information Science 49(1): 91-106.

Mirjat A.J., Wassan A.A., Shaikh S., 2017. Beggary in Hyderabad Division: A sociological analysis. Grassroots 51(2). Online: https://research-advances.org/index.php/RAJMSS/article/view/139/153 (accessed: 25 September 2019).

Paksi A.K., Budi N.N., Susanto N.N., 2006. Motivasi NonEkonomi Pengemis di Kota Yogyakarta (Non-economic motivation of urban beggars in Yogyakarta). Jurnal PKMP 3(18). Jurusan Hubungan Internasional Universitas Muhammadiyah, Yogyakarta.

Paramita D.A.M., Suresmiathi A.A., 2012. Sektor Informal, Pengangguran Dan Kemiskinan Di Provinsi Bali Tahun 2004-2012 (Informal sector, unemployment, and poverty in Bali Province 2004-2012). E-Jurnal Ekonomi Dan Bisnis Universitas Undayana 29-38.

[Perda] Peraturan Daerah Kota Denpasar Nomor 5 Tahun 2016 tentang Rencana Pembangunan Jangka Menengah Daerah (RPJMD) Semesta Berencana Kota Denpasar Tahun 2016-2021 ([Local Regulation] Denpasar City Local Regulation Number 5, 2016 regarding the Temporary Local Middle-Period Development Planning 2016-2021).

[Perda] Peraturan Daerah Kota Denpasar Nomor 27 Tahun 2011 tentang Rencana Tata Ruang Wilayah Kota Denpasar Tahun 2011-2031. ([Local Regulation] Denpasar City Local Regulation Number 27, 2011 regarding the Spatial Planning of Denpasar City 2011-2031).

Pérez-Muñoz C., 2018. Beneficence, street begging, and diverted giving schemes. Political Research Quarterly 71(4): 923-935.

Putri I.A.S.M., Yuliarmi N.N., 2011. Beberapa Faktor Yang Memengaruhi Tingkat Kemiskinan Di Provinsi Bali (Factors influencing the poverty rate in Bali, Indonesia). E-Jurnal Ekonomi Dan Bisnis Universitas Undayana 2(10): 441-448.

Qiao G., Chen N., Prideaux B., 2017. Understanding interactions between beggars and international tourists: The case of China. Asia Pacific Journal of Tourism Research 22(3): 272-283.

Saputra I.P.E., Dewi N.P.M., 2010. Pengaruh Tingkat Pendidikan, Struktur Ekonomi Dan Belanja Pembangunan
Terhadap Kemiskinan Provinsi Bali (The impact of education, economic structure and development expenditure on the poverty rate in Bali, Indonesia). E-Jurnal Ekonomi Dan Bisnis Universitas Undayana 4(2): 105-112.

Sekyere E.O., Jengre E., Alhaasan E., 2018. Begging in the city: Complexities, degree of organization, and embedded risks. Child Development Research. https://doi. org/10.1155/2018/9863410.

Setyaningrum N., 2014. Fenomena Pengemis Anak Di Pasar Klewer Surakarta (Phenomenon of child beggars in Klewer Market, Surakarta). Sosialitas: Jurnal Ilmiah Pendidikan Sosiologi-Antropologi 1-22.

Shara A.R.I.D, 2019. Karakteristik Dan Sebaran Pengemis Di Kawasan Sanglah Kota Denpasar (The characteristics and spatial distribution of beggars in the Sanglah Region, Denpasar, Bali). Thesis. Universitas Gadjah Mada, Yogyakarta.

Shara A.R.I.D., 2015. Studi Kasus Eksistensi Pengemis Tipe Baru di Kecamatan Denpasar Barat (The case of new beggars category emergence in West Denpasar District). Skripsi. Universitas Pendidikan Ganesha, Singaraja.

Sirojuzilam, 2006. Teori Lokasi. USU Press, Medan.

Social Service of Denpasar City, 2018. Daftar Gepeng yang Telah Dipulangkan Tahun 2018 (List of Homeless and Beggars Sent Home, 2018). Dinas Sosial Kota Denpasar, Denpasar.

Thamrin H., Ritonga F.U., 2018. Cutting off beggars spread in Medan. IOP Conf. Series: Earth and Environmental Science 126(1): 012162. doi:10.1088/1755-1315/126/1/012162.

Thomassen B., 2015. Begging Rome: Norms at the margins, norms of the in-between. Critique of Anthropology 35(1): 94-113.

Tribunenews.com 2018. "Para Pengemis di Bali Sanggup Setor Rp 1,5 Juta Per Bulan Agar Tak Diciduk" (Beggars in Bali to pay 1.5 million rupiahs (100USD) to prevent themselves of being arrested). Online: http://www. tribunnews.com/regional/2018/02/05/para-pengemisdi-bali-sanggup-setor-rp-15-juta-per-bulan-agar-tak-diciduk? page=all. (accessed: 25 November 2018).

Yunus H.S., 2010. Metode Penelitian Wilayah Kontemporer (Contemporary spatial study method). Pustaka Pelajar, Yogyakarta. 